„Studia Wyborcze”, tom 32, 2021

DOI: https://doi.org/10.26485/SW/2021/32/6

\author{
Alena Krunková* \\ (iD) https://orcid.org/0000-0002-4327-4795
}

\title{
REFERENDUM IN THE SLOVAK REPUBLIC. THEORY AND PRACTICE
}

\section{INTRODUCTION}

In the recent period, a discussion on the referendum has been again reopened among the professional and lay public in the Slovak Republic. Apart from a new, publicly interesting topic COVID-19, a word referendum has become a highly frequent term for some time in connection with its holding in order to shorten the electoral term of the National Council of the Slovak Republic (hereinafter also "the Parliament") and subsequently call early parliamentary elections. At the beginning of the year 2021, the political parties forming the opposition in the Parliament initiated the necessary activities aimed at calling a referendum on the basis of the citizens' petition according to Art. 95.1 of the Constitution of the Slovak Republic No. 460/1992 Coll. as amended (hereinafter also "the Constitution of the Slovak Republic" or "the Constitution"). The Committee on Petitions submitted a petition for declaring a referendum on early elections in the registry of the Presidential Palace on May 3, 2021, with more than 600,000 signatures. Subsequently, the President of the Slovak Republic (hereinafter "the President") turned in accordance with Art. 95.2 of the Constitution of the Slovak Republic to the Constitutional Court of the Slovak Republic (hereinafter also "the Constitutional Court") to assess whether the subject matter of the proposed referendum is or is not in conformity with the Constitution of the Slovak Republic. On July 7, 2021, the

\footnotetext{
* Doc. JUDr. Alena Krunková, Ph.D., Pavel Jozef Šafárik University in Košice, Faculty of Law, Department of Constitutional Law and Administrative Law, alena.krunkova@upjs.sk
} 
Constitutional Court at a private hearing decided that the referendum question under review is unconstitutional; three judges of the thirteen-member Plenum of the Constitutional Court attached their separate opinions to this decision. On the basis of the above, it is possible to agree with the view that the referendum, as one of the most well-known forms of direct democracy, is justified at every stage of the life of society. However, in contemporary statehood it must be seen as a supplementary element in the decision-making mechanism of representative democracy [Dobrovičová, Krunková 2018: 590]. In this context, the ambition of this paper is to pause on the existence of the referendum on the territory of the Slovak Republic since 1993, both in terms of its legal regulation as well as practical implementation.

\section{REFERENDUM FROM THE PERSPECTIVE OF THE CONSTITUTION OF THE SLOVAK REPUBLIC}

The essence of the referendum, as one of the most used elements of direct democracy in terms of the classical principles of democracy and sovereignty of the people, is declared by the Constitution of the Slovak Republic already in its introductory provisions by laying down the exercise of state power in two equivalent ways - directly or by electing its representatives (Art. 2.1). For the sake of completeness, it should be added that the elements of direct democracy are mentioned in the original text of the Constitution of the Slovak Republic in other provisions - Art. 7.1, Art. 30.1, Art. 67, Art. 93-100, Art. 106. The development of society and the actual exercise of direct democracy gradually changed the legal regulation of its forms. There have been more significant changes in the regulation ex lege, as all forms of direct democracy provided for ex constitutione are directed by blanket reference to the relevant specific legislation. The following types (forms, institutes) of direct democracy result from the constitutional regulation:

- national referendum (Art. 7.1, Art. 93-100 of the Constitution of the Slovak Republic);

- local referendum and referendum on the territory of a higher territorial unit (Art. 67 of the Constitution of the Slovak Republic);

- assembly of the inhabitants of the municipality (Art. 67 of the Constitution of the Slovak Republic);

- plebiscite on the recall of the President (Art. 106 of the Constitution of the Slovak Republic).

All these forms of direct democracy (with the exception of assemblies of the inhabitants of the municipality) are at the same time certain forms of referendum - referendum as decision making of citizens by expressing their 
opinion on the issue forming the subject matter of the referendum by choosing from yes or no options). Given the scope of the matter, we will further focus only on the national referendum, which is also defined as a form of state power. Everywhere in this paper the term referendum is used this means a national referendum.

In terms of the structural arrangement of the Constitution of the Slovak Republic, the regulation of the referendum can be found in Chapter Five, Section Two (Art. 93-100). The title of this chapter is "Legislative Power". The legislator probably meant to emphasize the fact that legislative power in the Slovak Republic can be exercised besides the Parliament (Chapter Five, Section One of the Constitution) equally by the citizens through a referendum. From a certain point of view, this fact can be viewed positively. However, the constituent articles of the Constitution which create the concept of admissible forms (types) of referendum, as well as its practical implementation, aspire to the opposite evaluation.

\section{MANDATORY REFERENDUM}

From the substantive point of view, the Constitution distinguishes between obligatory and optional referendum. The provisions of the Constitution of the Slovak Republic concerning the regulation of the obligatory referendum appear to be the least controversial (Art. 93.1 and Art. 7). In this context (Art. 93.1), it is necessary to hold a referendum if the Parliament adopts a constitutional law on joining a state union with other states or on secession from such a union. The Constitution itself lays down the obligation to call and hold a referendum in case of such a situation. It was confirmed also by the opinion of the Constitutional Court of the Slovak Republic - "Mandatory referendum can be defined as a referendum by which a fundamental decision of the Parliament, whose nature is defined by the Constitution, must be approved by the citizens." (II. ÚS 31/97).

This referendum is a necessary precondition for the effectiveness of the constitutional law which the Slovak Republic would join a state union with other states (or would secede from such a union). Therefore, it is also a ratification referendum, as without a positive result of this referendum the constitutional law will not enter into force and the effects arising from it (the entry of the Slovak Republic into the state union) will not be valid. If the constitutional bodies decided to join a state union with another state or states, it would be up to the citizens of the Slovak Republic to express their opinion whether or not they accept the will of their legitimately elected state bodies. If the result of the referendum was positive, the constitutional law would enter into force. At the 
same time, the Constitution would be also changed and the subsequent decision making of the Parliament would no longer be necessary. If the opinion expressed in the referendum was negative, the nation would exercise their right of veto and the discussion on joining the state union (or secession from it) would have to be postponed for at least 3 years in accordance with Art. 99.2 of the Constitution. The adopted constitutional law would thus not enter into force. The results of the referendum would cause the o of a valid but not yet effective constitutional law. The Constitution does not explicitly state the obligation to repeal it. It would probably be up to the National Council of the Slovak Republic what position to take on the constitutional law in question. In the Slovak Republic, this type of referendum has not taken place on grounds of the relevant articles of the Constitution yet.

\section{OPTIONAL REFERENDUM}

In the Slovak Republic, the optional referendum is the referendum which is affected by frequent interpretative inconsistencies and problems. The Constitution of the Slovak Republic in Art. 93.2 determines for decision making "also other important issues of public interest". In this type of referendum, optionality appears in two ways:

1. As a possibility to hold a referendum on other important issues of public interest, i.e. optional nature of the subject matter.

2. As a possibility to initiate a referendum (to initiate its performance), i.e. optionality of the initiation of referendum.

In this context, it is probably worth noting that at the moment of meeting the constitutional and statutory requirements for its realization, the optional referendum acquires character of obligation, i.e. it must take place (Art. 95 of the Constitution of the Slovak Republic). From the terminological phrase "Other important issues of public interest may also be decided by the referendum." one could assume that it will be an imperative decision-making referendum, the results of which (positive or negative) will designate immediate legal effects. However, neither the Constitution nor the implementing law provides in any of its provisions a guarantee mechanism for achieving these effects. What legal effects the results of the referendum could have (and whether they could have any at all) also depends to a large extent on the issue which forms the subject matter of the referendum.

The Constitution of the Slovak Republic defines the subject matter of the referendum in a positive as well as in a negative way. The wording of Art. 93.2 ("Other important issues of public interest may also be decided by the referendum.") [Ut2] allows the subject matter of the referendum to be interpreted in 
almost unlimited way. The Constitution conditions it only with two facts - the importance of the issue (issues) and the evidence of existence of the public interest. The subject matter of the referendum is partly specified by the implementing act, which imposes the obligation to formulate the question in such a way that it can be answered unequivocally yes or no. If the subject matter of a referendum consists of several questions, they cannot condition each other. If needed, it is necessary to attach an annex to the question, which will clarify or specify the subject matter of the referendum. This emphasizes the fact that the issue of the referendum in its entirety should be intelligible to the average citizen, i.e. at least to the assumed absolute majority of eligible voters, which forms, according to Art. 98.1 of the Constitution, quorum for the validity of the results of the referendum.

According to Art. 93.2 of the Constitution of the Slovak Republic, the fundamental rights and freedoms, taxes, levies and state budget may not be the subject matter of referendum. The legislator did not clarify the assessment of the importance of the issue raised in a referendum. Apparently, it is considered that the question raised in a referendum gains importance by the fact that the subjects initiating the respective referendum stand up for it [Čič a kol. 2012: 163]. The importance of the subject matter of a referendum, i.e. the issue on which the voters are to express their opinion in the referendum, is also confirmed by the unsuccessful history of national referendums held in the Slovak Republic, which will be addressed later.

According to Art. 95.1 of the Constitution of the Slovak Republic, a referendum may be initiated by two subjects:

1. Citizens of the Slovak Republic if at least 350,000 citizens request by petition to call a referendum.

2. The Parliament by its resolution, while a proposal for the adoption of the resolution of the National Council of the Slovak Republic on the call of a referendum may be submitted by the deputies of the National Council of the Slovak Republic or by the Government of the Slovak Republic (Art. 96.1).

The referendum is announced by the President of the Slovak Republic (Art. 95 of the Constitution of the Slovak Republic). The President of the Slovak Republic plays an important role in connection with the referendum. The Constitution of the Slovak Republic entrusts him/her with the power to announce a referendum as a constitutional official and a guarantee of the direct implementation of expression of the sovereignty of the people, provided that the required conditions are met. In this context, the President can be seen as an intermediary for the direct exercise of state power, who, at the same time, sets a date for the holding of referendum in accordance with the procedural provisions ex constitutione, so that it is held within 90 days from its announcement (Art. 96.2, Art. 97.1 and 2). Before announcing the referendum, 
he/she may also submit to the Constitutional Court of the Slovak Republic a proposal for decision whether the subject matter of the referendum to be declared on the basis of the petition or the resolution of the National Council of the Slovak Republic is in conformity with the Constitution or a constitutional law. If the President submits such a proposal to the Constitutional Court of the Republic, the time limit for announcing the referendum does not run from the submission of this proposal until the decision of the Constitutional Court of the Republic becomes final (Art. 95.2).

The Constitution establishes the same conditions for the validity of mandatory referendum and optional referendum (Art. 98.1). It requires that an absolute majority of eligible voters would take part in it and that the decision would be taken by an absolute majority of the participants of the referendum. It assumes a cumulative engagement of both conditions, otherwise the referendum is considered invalid. The constitutional conception, we perceive the citizens of the Slovak Republic as subjects of referendum in two levels - firstly, as subjects to whom the Constitution grants the possibility to initiate a referendum, and secondly, as subjects allowed by legal order in force to vote in an already announced referendum [Somorová 2000: 24].

Proposals adopted in the referendum are promulgated by the National Council of the Slovak Republic in the same way as a law (Art. 98.2 of the Constitution of the Slovak Republic). The result of the referendum can be amended or repealed by the National Council of the Slovak Republic by its constitutional law once a period of three years since its effectiveness has elapsed (Art. 99.1 of the Constitution of the Slovak Republic). A referendum on the same matter can be repeated no earlier than three years after the referendum has been held (Art. 99.2 of the Constitution of the Slovak Republic).

\section{DEVELOPMENT OF THE LEGISLATIVE REGULATION OF THE REFERENDUM IN THE SLOVAK REPUBLIC}

Although the Constitution of the Slovak Republic contains a rather extensive regulation of the national referendum (Art. 93-100) and devotes to it a separate section, it does not cover all its aspects. The constitutional blanket statement of Art. 100 stipulates that the manner of holding a referendum will be laid down by law. The Act No. 564/1992 Coll. on the Manner of Holding a Referendum, as amended (hereinafter also the "Act on the Manner of Holding a Referendum") was the first specific regulation ex lege. This implementing act was adopted on November 19, 1992, i.e. it was created at the time of the common Czechoslovak state, as a reaction to the blanket constitutional rule of the Constitution of the Slovak Republic. In its provisions, the provisions of relevant 
electoral laws, first the Act No. 80/1990 Coll. on Elections to the Slovak National Council, as amended, and subsequently the Act No. 333/2004 Coll. on Elections to the National Council of the Slovak Republic were alternatively used. This fact was also logically justifiable, since the mechanism of conducting the referendum is in many ways similar to the mechanism of conducting elections.

In 2014, in the area of electoral law in the Slovak Republic, the so-called Electoral Code was adopted - the Act No. 180/2014 Coll. on the Conditions of Exercise of Right to Vote and on amendments and additions to certain acts, the purpose of which was a comprehensive concept and harmonization of terminological inconsistencies in the exercise of right to vote in the Slovak Republic. A national referendum has also been included in the above-mentioned law, which is thus considered to be a type of election or one of the types of the exercise of right to vote ( $\$ 1$ of the above-mentioned law). It is not possible to agree unreservedly with the above-mentioned concept, since it is a combination of the direct exercise of state power with its exercise in a representative manner [Krunková 2010: 144].

The Electoral Code regulates the conduct of referendum in its eighth part in §196-215. The previous law on the manner of holding the referendum contained a fairly decent set of procedural rules for the implementation of an announced national referendum. On the referendum issue, the legislation concerning the conduct of the referendum was considered to be the least problematic. The relevant provisions of the Electoral Code were based on the concept of the previous law; the change was made in relation to voting outside the territory of the Slovak Republic. The Electoral Code allows people to participate in the referendum by casting a vote by correspondence. The very method of realization of the referendum by post is set out in $\$ 205, \S 207$ and $\$ 208$. Pursuant to $\S 205$, the method of voting on the territory of the Slovak Republic and outside the territory of the Slovak Republic is equal for certain categories of persons. Thus, an answer to a question asked in the referendum may be sent by post either by a person who is a citizen of the Slovak Republic but for various reasons resides outside the territory of the Slovak Republic (\$205, sec. 3, letter a) and §207) or by a person who is a citizen of the Slovak Republic, resides on the territory of the Slovak Republic, but at the time of the referendum stays outside the territory of the Slovak Republic ( $\$ 205$, sec. 3, letter b) and $\S 208)$. Despite the changed conditions of the legal regulation and a certain increased interest in "foreign Slovaks", the condition of citizenship remains an obligatory condition for exercising the right to vote in the referendum. Voting in the referendum on the basis of written correspondence is therefore similar principles as the possibility to vote by post in the case of the elections to the National Council of the Slovak Republic. It can only be implemented on the basis of an application (request), while a citizen of the Slovak Republic who does not 
have permanent residence on the territory of the Slovak Republic communicates in this case with the Ministry of Interior of the Slovak Republic. The application for a postal vote must be received no later than 50 days before the date of the referendum; the application received after the deadline is disregarded ( $\$ 207$, sec. 1$)$; the Ministry sends the written correspondence necessary for the vote no later than 35 days before the date of the referendum. The time limits thus established give ample opportunity for exchange of correspondence, since the logistics of voting is a two-envelope system - the referendum voter circles a "yes" or "no" answer on the ballot, places it in an envelope, and places the sealed envelope in a return envelope (marked VOTE BY MAIL), which he or she mails $(\$ 207$, sec. $5,6,7)$. In the second case, i.e. if a citizen of the Slovak Republic with permanent residence on the territory of the Slovak Republic expresses interest in voting in the referendum, but at the time of the referendum he/she will not stay in the territory of the Slovak Republic, he/she communicates with the relevant municipality in which his/her permanent residence is registered $(\S 208$, sec. 1$)$.

\section{NATIONAL REFERENDUM - APPLICATION IN PRACTICE}

Since 1993, the interest in using the national referendum has been relatively high in the Slovak Republic. The very first attempt to call it was a year and a month after the entry into force of the Constitution of the Slovak Republic. The petition of eligible citizens from February 1994 regarding the adjustment of the parliamentary mandate in the event that a deputy ceased to be a member of the political movement or political party for which he or she stood as a candidate in the elections to the National Council of the Slovak Republic, the proof of the origin of the funds used for privatisation, and the shortening of the electoral term. However, the petition contained only 232951 valid signatures, so the President did not call the referendum. Although the first attempt was not successful due to the insufficient number of signatures, the interest in using the referendum remained relatively high. From 1994 to 2004, there were 8 attempts to call a referendum in Slovakia, 6 of which were announced by the President, but only one (on the accession of the Slovak Republic to the European Union, which took place on May 16 and 17,2003) was successful. After this period, the referendum initiative slowed down a bit. Another referendum was held in 2010, then in 2015. The last attempt to hold a national referendum was in May 2021. Thus, in total, 8 national referendums were held, 3 other attempts to hold a referendum were not announced, but only one achieved valid effects [Dobrovičová, Krunková 2019: 590]. The high number of unsuccessful referendums naturally prompted an examination of its 
legislative regulation The constitutional concept of referendum in the Slovak Republic was originally enshrined in such a way that it sounded progressive for its time and allowed its use in a truly broad spectrum of social issues [Nikodým 2002: 405]. Even in the framework of numerous amendments to the Constitution, the concept of referendum was changed only once (Constitutional Act No. 90/2001 Coll.), when, for the President in doubt about the subject matter of the referendum, the possibility to request the Constitutional Court of the Slovak Republic to assess the conformity of the subject matter of the referendum with the Constitution of the Slovak Republic was provided for (Art. 95.2). Thus, an element of preventive control of constitutionality was introduced into the legal order of the Slovak Republic. In practice, this competency has been used twice so far, in 2014 and in 2021.

However, more problematic points have appeared over time mainly the absence of the imperativeness of the results of the referendum, the high quorum for the success of the referendum, the ambiguously specified subject matter of the referendum, the unidentifiability of the results of the referendum in the framework of the sources of law, or, in the light of the new legislation, the inconsistent legal regulation of the manner of conducting the referendum [Krunková 2010: 72]. The Constitutional Court of the Slovak Republic has taken a position on some of them in its decision making. In its proceedings, among other things, Article 72 and Article 93.2 of the Constitution of the Slovak Republic have been interpreted. The decisions of the Constitutional Court of the Slovak Republic - II. ÚS 31/97 of 21 May 1997, PL. ÚS 24/2014 of 28 October 2014 and PL. ÚS 7/2021 of 7 July 2021 were particularly significant in this respect. The most problematic issue was the determination of the binding nature of the results of the referendum, and, in particular, in the sense of whether they oblige the members of the National Council of the Slovak Republic to adopt a law corresponding to the results of the referendum.

The controversial decision was the very first of the above mentioned decisions, namely Ruling II. ÚS 31/97 of 21 May 1997. The Constitutional Court of the Slovak Republic, instead of interpreting Article 72 and Article 93.2 to bring clarity to the legal order regarding the subject matter of the referendum, has reached a conclusion that is incoherent. On the one hand, the Constitutional Court admits that "the Constitution of the Slovak Republic does not prohibit the subject matter of a referendum under Article 93.2 of the Constitution to be a question of amending the Constitution or a part of it", but, on the other hand, it adds that "the Constitution cannot be amended directly on the basis of voting in referendum." The decision further states that "the Constitution does not expressly provide for, nor does it empower the legislator, to include as an annex to a referendum question a draft of a constitutional law... The adoption of a proposal in a referendum has constitutional relevance in the sense that by it 
the citizens participating in the vote give order to the Parliament to amend the part of the Constitution which was the subject matter of the announced referendum in accordance with the proposal adopted in the referendum." (II. ÚS 31/97).

Another interest of society was aroused by the Finding PL. ÚS 24/2014 of 28 October 2014, in which the Constitutional Court ruled pursuant to Art. $125 \mathrm{~b}$ of the Constitution. It was the first ever decision under the so-called preventive review of constitutionality, when the President turned to the Constitutional Court with a request to assess whether the subject matter of the referendum proposed by the citizens' petition was in conformity with the provisions of the Constitution of the Slovak Republic. This referendum was referred to as the "Referendum on Marriage", it was initiated on the basis of a citizens' petition and it combined 4 questions:

1. Do you agree that marriage cannot be called any other cohabitation of persons other than a union between one man and one woman?

2. Do you agree that same-sex couples or groups of people should not be allowed to adopt children and raise them?

3. Do you agree that no other cohabitation of persons besides marriage should be granted the special protection, rights and obligations which, as of 1 March 2014, are granted by legal norms only to marriage and spouses (in particular, recognition, registration or registration as a community of life before a public authority, the possibility of adoption of a child by the other spouse of a parent)?

4. Do you agree that schools should not be able to require children to participate in classes on sexual behaviour or euthanasia if their parents or the children themselves disagree with the content of the classes?

The Constitutional Court found the third question to be unconstitutional and so the referendum was held on only three questions. In its reasoning, it stated that "it is therefore not possible to conclude from the Constitution an obligation on the part of a member of the Parliament to contribute, by vote, to the transformation of a proposal adopted in a referendum into an adequate form of text of the legal regulation. There is no legally regulated sanction that can be applied against a member of the Parliament if he or she votes against the will expressed by the citizens in a valid referendum. Any consequences that could be drawn from such a situation are reduced to the level of political responsibility." (PL. ÚS 24/2014).

The latest decision of the Constitutional Court on the issue of referendum is the Finding PL. ÚS 7/2021 of 7 July 2021, mentioned in the introduction to this paper. This decision was expected by the public as it concerned the referendum on the so-called early parliamentary elections. On a similar issue of shortening the electoral term of the National Council of the Slovak Republic, a referendum has already been announced twice in the past (in November 
2000 and in April 2004), it was held, but not once did it reach the required quorum of participation of an absolute majority of all eligible voters, thus it was not valid.

Also in this case, the Constitutional Court decided pursuant to Article $125 \mathrm{~b}$ of the Constitution, i.e. on the basis of preventive review of constitutionality. Already in the previous, historically first decision, within this type of constitutional review, the Constitutional Court defined its approach to preventive constitutional review as follows:

Use of the competence under Article $125 \mathrm{~b}$ of the Constitution entails a fundamental legal consequence - the original bearer of state power, to whom this power (even in its jurisdictional form) is ultimately given at the service, will definitely not be able to resolve a socially pressing topic, which thus remains on the shoulders of the legislative, executive and judicial bodies, which, although they have a high quality professional background, are exempted from the direct decision making on their own legal status. Thus, the Constitutional Court will disallow the actors of state power to express themselves in a legally binding way on an urgent issue, even before it is possible to know what form the final result of the referendum would take. At the same time, the solution of society-wide problematic issues is most acceptable when it has a high degree of legitimacy. In the opinion of the Constitutional Court, this condition is met by the referendum in the Slovak constitutional system, and thus the position of the Constitutional Court on the use of competence pursuant to Art. $125 \mathrm{~b}$ of the Constitution must be very careful. (PL. ÚS 24/2014).

Nevertheless, in its decision of 7 July 2021, the Constitutional Court stated that

The subject matter of the referendum with the question with the wording: «Do you agree to shorten the 8th electoral term of the National Council of the Slovak Republic so that the elections to the National Council of the Slovak Republic are held within 180 days from the date of the announcement of the results of this referendum?» is not in conformity with Art. 1.1 and Art. 1.1 in conjunction with Art. 73.1, Art. 81a, Art. 82.5 and Art. 93.3 of the Constitution of the Slovak Republic.

While justifying the decision, the Constitutional Court relied on its previous decisions concerning the issue of the referendum but it also linked the matter under review with the so-called breakthrough decisions concerning the material core of the Constitution (PL. ÚS 7/2017and PL. ÚS 21/2014). In particular, the Constitutional Court examined whether the subject matter of the referendum does not undermine with constitutional intensity the material core of the Constitution, since, on the one hand, it admitted that changes to the Constitution may also affect the material core of the Constitution, but, on the other hand, such a change cannot undermine the material core with constitutional intensity (PL. ÚS 21/2014). According to the case law of the Constitutional Court, an amendment to the Constitution concerning the material core is admissible, but it must not change the character of the Slovak Republic as a democratic state governed by the rule of law. 


\section{As stated in the reasoning of the decision in question,}

Although the Constitution allows also the shortening of the four-year term of the National Council of the Slovak Republic by dissolving it pursuant to Art. 102.1(e) and Art. 106.3 of the Constitution, it does not explicitly allow the shortening of the electoral term of the National Council by a referendum. However, the subject matter of the referendum does not relate to any of the constitutionally recognised grounds that would legitimise the early termination of the electoral term of the National Council of the Slovak Republic.

\section{At the same time, the Constitutional Court stated that}

A referendum, however, cannot result in a rule whose regulatory essence consists in the short-term and temporary suspension of a general norm of the Constitution forming part of the material core, for the sake of an individual case. The proposal adopted in the disputed referendum would mean that although the elections would have to take place within a period not exceeding the 8th electoral term of the National Council of the Slovak Republic, however, the prescribed regularity of this particular electoral term would be disrupted, which would at the same time suspend Art. 73.1 of the Constitution (item 127 of the reasoning). The subject matter of the referendum at issue is thus characterized by a unique and at the same time constitutionally impermissible absence of generality. Allowing such a referendum practice would ultimately lead to a result where the power established (in a referendum) in individual cases would preclude the application of the still effective general rules established by the constituent power and forming part of the material core of the constitution.

In its reasoning, the Constitutional Court also commented on previous referendums held on similar issues

As obiter dictum in this part of the reasoning, the Constitutional Court states that the adoption of constitutional laws by the Parliament shortening its electoral term on an ad hoc basis in the past, as well as the invalid referendums on the early termination of the electoral term of the National Council of the Slovak Republic held in 2000 and 2004, do not constitute a relevant argument in favour of the conclusion on the conformity of the disputed subject matter of the referendum with the Constitution. The constitutionality of these laws and referendums could not be confirmed by the Constitutional Court because they were not subject to its review (although it should be noted that already in its decision in the case II.ÚS 153/2013 the Constitutional Court stated in obiter dictum that it "perceives the imperfection or questionability of the method of self-dissolution of the Parliament by an ad hoc constitutional law and the problematic nature of ad hoc constitutional laws in general", which was also pointed out by the National Council of the Slovak Republic in its statement). Taking into account the conclusions of the Constitutional Court expressed in this finding, it can be stated that the views of the Constitutional Court would be analogous in case of the evaluation of the above-mentioned referendums as well as constitutional laws. The one-time breach of rules regulated by the Constitution does not fit even to the legislature and is not considered by the Constitutional Court to be an appropriate constitutional practice. 


\section{CONCLUSION}

Referendum, as an element of direct democracy that allows participation in the decision-making processes of the state, has not lost its popularity even in the twenty-first century. The Slovak Republic is an example of this. Certainly, its implementation is different than it was in the past, although, on the other hand, it could be a bit easier thanks to modern technology. As the interest of society is formed, so is the subject matter of the referendum. With some generalisation, we can see a certain connection with the popularity of referendum, for example in the context of escalated social events. Particularly in recent period, there has been a tendency to accelerate the referendum as a coercive mechanism, a threat, or a means of protest that will "surely achieve the will of the people", i.e. the desired outcome of the referendum organisers. Whatever the motives for its implementation are, the truth is that a more effective mechanism for testing the will of the widest possible spectrum of the population has not been found. We therefore believe that it is always in some way risky not to allow such an expression of the will of the citizens, even if it is done on the basis of a decision of the highest judicial authority.

\section{REFERENCES}

Butler David, Ranney Austin (eds.). 1994. Referendums around the World. The Growing Use of Direct Democracy. Washington D.C.: The AEI Press.

Dobrovičová Gabriela, Krunková Alena. 2019. Referendum v Slovenskej republike v ústavnej kontinuite Československa. In Ústavni kontinuita České republiky s československou tradici. Red. Aleš Gerloch, Katarzyna Žák Krzyžanková. Plzeň: Aleš Čeněk.

Čič Milan a kol. 2012. Komentár k Ústave Slovenskej republiky. Bratislava: Eurokódex.

Krunková Alena. 2010. Verejná moc a priama demokracia. Košice: Univerzita Pavla Jozefa Šafárika v Košiciach.

Nikodým Dušan. 2002. "Referendum (aktuálne otázky)”. Právny obzor 5-6.

Somorová L'udmila. 2000. "Referendum ako forma výkonu štátnej moci”. Ústavnost' a politika $2(3)$.

\section{LEGAL ACTS}

Ruling of the Constitutional Court of the Slovak Republic II. ÚS 31/97 of 21 May 1997. Finding of the Constitutional Court of the Slovak Republic II. ÚS 9/00 of 7 February 2001. Finding of the Constitutional Court of the Slovak Republic II. ÚS 105/03 of 8 October 2003. 


\section{Summary}

This article deals with the fundamental form of direct democracy - a referendum in terms of its constitutional regulation and practical implementation in the Slovak Republic. It analyses the constitutional concept of the referendum with an emphasis on its legislative development and practical implementation within the functioning of the independent state after the year 1993. It points out some interpretative problems arising from the application practice and examines its constitutional implications relying on the relevant case law of the Constitutional Court of the Slovak Republic.

Keywords: referendum, constitutional development, the Constitution of the Slovak Republic, case law.

\section{REFERENDUM W REPUBLICE SŁOWACKIEJ. TEORIA I PRAKTYKA (streszczenie)}

Tematem artykułu jest referendum jako podstawowa forma demokracji bezpośredniej, jego regulacja konstytucyjna i praktyczne zastosowanie w Republice Słowackiej. Poddano także analizie konstytucyjną koncepcję referendum, z naciskiem na jego rozwój legislacyjny i praktyczne wdrożenie w ramach funkcjonowania niepodległego państwa po 1993 roku. Wskazano na pewne problemy interpretacyjne wynikające z praktyki aplikacyjnej oraz jej konstytucyjne implikacje, opierając się na orzecznictwie Trybunału Konstytucyjnego Republiki Słowackiej.

Słowa kluczowe: referendum, rozwój konstytucyjny, Konstytucja Republiki Słowackiej, orzecznictwo. 